\title{
Risiko Produksi Karet Petani di Kecamatan Kejuruan Muda Kabupaten Aceh Tamiang
}

\author{
Fifi Ariska Siregar 1*, Fiddini Alham², Thursina Mahyuddin ${ }^{3}$, Muslimah $^{4}$ \\ 1,2,3,4 Prodi Agribisnis Fakultas Pertanian Universitas Samudra, Indonesia. \\ *Corresponding author's e-mail: fiddinialham@unsam.ac.id
}

\begin{abstract}
ABSTRAK
Tujuan penelitian ini untuk mengetahui sumber risiko produksi karet, menganalisis pengaruh dari faktor-faktor sumber risiko produksi dan fluktualitas harga dalam mempengaruhi produksi karet di Kecamatan Kejuruan Muda Kabupaten Aceh Tamiang. Metode penelitian yang digunakan adalah survei. Analisis sumber risiko produksi karet alam dilakukan dengan menggunakan persamaan regresi linier berganda dengan variabel bebas yaitu jumlah pohon yang mati, jumlah pohon yang terkena penyakit, cuaca/curah hujan dan produksi bulan sebelumnya serta variabel terikat yaitu produksi. Adapun sumber-sumber risiko produksi karet alam di Kecamatan Kejuruan Muda yaitu cuaca/iklim serta hama dan penyakit. Variabel jumlah pohon mati dan variabel jumlah pohon yang terkena penyakit berpengaruh terhadap produksi karet di Kecamatan Kejuruan Muda.
\end{abstract}

Kata Kunci:

karet; petani; risiko; produksi

\begin{abstract}
The aim of this research to know source of risk of rubber production, to analyze the affected of rubber production factors and price fluctuation affected of rubber production in Kejuruan Muda district, Aceh Tamiang region. The method used a survey. Analyze of rubber production of source of risk used multiple linier regression with independent variable are number of rubber tree died, number of disease tree, climate and production month before and dependent variable is production. The sources of rubber production risk is climate and pest. The number of died tree and tree with disease affected rubber production.
\end{abstract}

Keyword:

rubber; farmer; risk; production

How to Cite: Siregar, F.A, F. Alham, T. Mahyuddin, Muslimah., Risiko Produksi Karet Petani di Kecamatan Kejuruan Muda Kabupaten di Aceh Tamiang. Jurnal Penelitian Agrisamudra. 6(1):

\section{Pendahuluan}

Karet merupakan salah satu komoditi perkebunan penting, baik sebagai sumber pendapatan, kesempatan kerja dan devisa, pendorong pertumbuhan ekonomi sentrasentra baru diwilayah sekitar perkebunan karet maupun pelestarian lingkungan dan sumberdaya hayati. Adapun data luas areal dan produksi karet perkebunan rakyat di Indonesia pada tahun 2013 sampai 2017 dapat dilihat pada Gambar 1. 


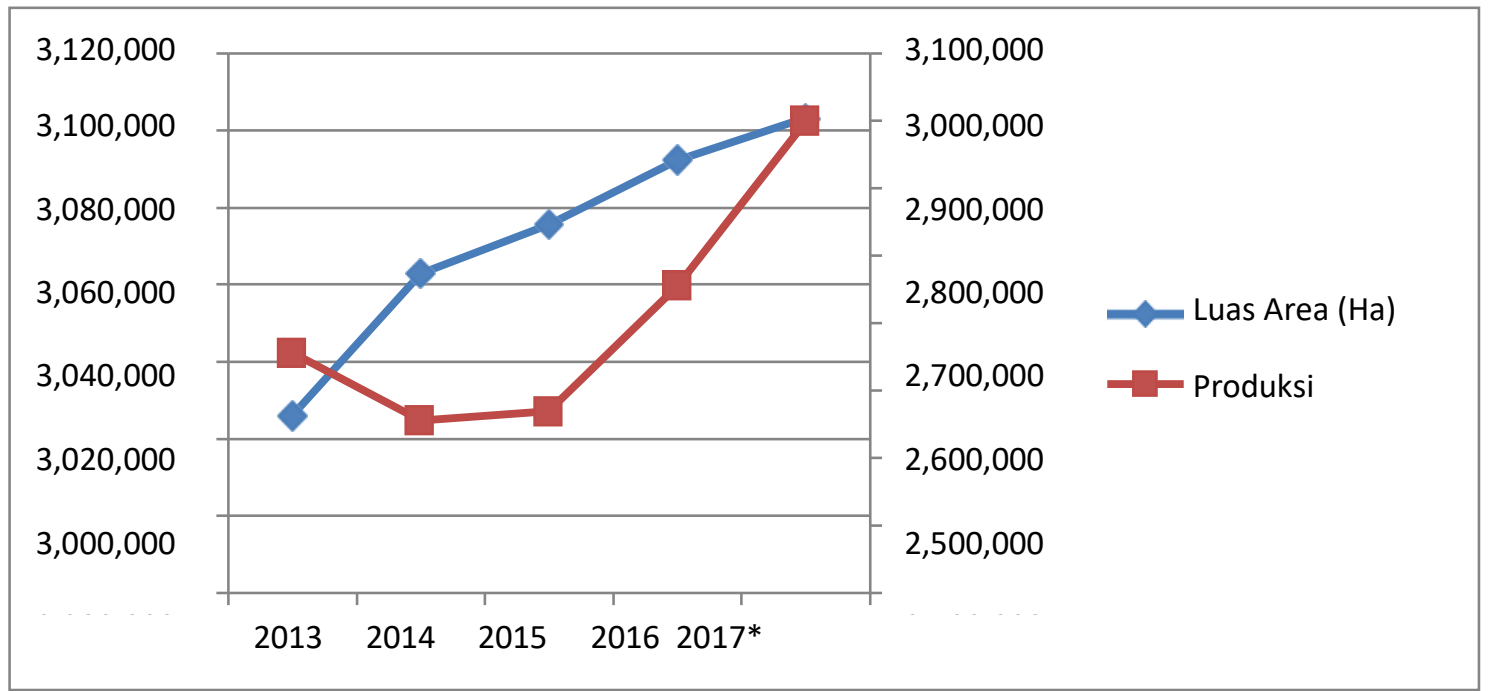

Gambar 1. Luas Areal dan Produksi Karet Perkebunan Rakyat di Indonesia Pada

Tahun 2013-2017

Berdasarkan gambar diatas dapat dilihat, luas areal perkebunan karet rakyat Indonesia dari tahun 2013 sampai 2017 terus mengalami peningkatan. Sementara untuk produksi karet dari tahun 2013 sampai 2014 mengalami penurunan sedangkan tahun 2015 sampai 2017 mengalami peningkatan. Hal ini dapat terjadi dikarenakan harga karet dunia yang masih berfluktuatif, sehingga mempengaruhi hasil produksi karet perkebunan rakyat. Sejumlah lokasi di Indonesia memiliki keadaan lahan yang cocok untuk pertanaman karet, sebagian besar berada di wilayah Sumatera, salah satunya provinsi Aceh. Hal ini dapat dilihat dari data luas areal perkebunan karet di Aceh pada Gambar 2. Terlihat jelas bahwa luas areal perkebunan karet Aceh dari tahun 2013 sampai 2014 mengalami penurunan, kemudian mengalami peningkatan pada tahun 2014 sampai 2017.

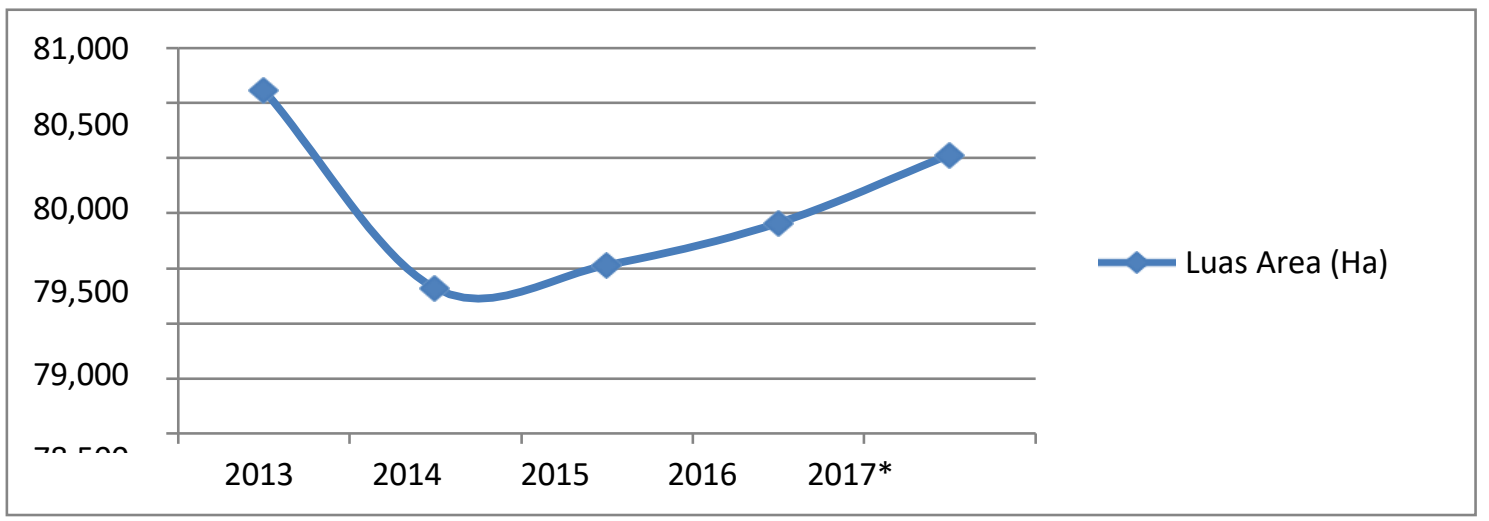

Gambar 2. Luas Areal Karet Perkebunan Rakyat di Aceh Pada Tahun 2013-2017

Luas areal tanaman perkebunan yang masih cukup luas di daerah Aceh tidak selalu berkorelasi dengan produksi tanaman karet yang dihasilkan. Hal ini dapat disebabkan oleh beberapa faktor-faktor yang mempengaruhi hasil tanaman. Sementara untuk produksi tanaman karet perkebunan rakyat di Aceh pada tahun 2013 sampai 2017 dapat dilihat pada Tabel 1.

Tabel 1. Produksi Tanaman Karet Perkebunan Rakyat Aceh 2013 Sampai 2017 (Ton) 


\begin{tabular}{cc}
\hline Tahun & Produksi (Ton) \\
\hline 2013 & 57.042 \\
2014 & 56.780 \\
2015 & 56.455 \\
2016 & 66.225 \\
$2017^{*}$ & 78.739 \\
\hline
\end{tabular}

Sumber : Direktorat Jenderal Perkebunan (2017)

Berdasarkan Tabel 1, terlihat jelas bahwa total produksi karet di Aceh mulai tahun 2013 sampai 2015 mengalami penurunan dan kemudian mengalami peningkatan pada tahun 2016 sampai 2017. Fluktuasi produksi menjadi suatu permasalahan yang dihadapi oleh petani karet saat ini. Hal ini dapat diakibatkan oleh beberapa faktorfaktor sumber risiko produksi, seperti curah hujan, hama, dan penyakit juga menjadi suatu kendala yang menyebabkan total produksi karet alam setiap tahun mengalami ketidaktetapan dengan luas lahan setiap tahun yang meningkat. Penanganan yang tepat sangat dibutuhkan untuk mengurangi risiko tersebut agar dapat menghasilkan produksi maksimal dengan kualitas atau standar mutu karet alam yang diharapkan oleh petani sesuai permintaan pasar domestik maupun internasional. Risiko produksi merupakan risiko yang sangat berpengaruh dalam perkebunan karet rakyat.

Aceh Tamiang merupakan salah satu kabupaten baru, hasil pemekaran dari kabupaten induk Aceh Timur pada tahun 2002. Kabupaten ini memiliki berbagai potensi unggulan disektor perkebunan salah satunya perkebunan karet. Hal ini dapat dilihat dari luas areal dan produksi karet Kabupaten Aceh Tamiang pada Tabel 2.

Tabel 2. Luas Lahan dan Produksi Tanaman Karet Perkebunan Rakyat Aceh Tamiang Tahun 2013-2017 (Ton)

\begin{tabular}{ccc}
\hline Tahun & Luas Lahan $(\mathrm{Ha})$ & Produksi $($ Ton $)$ \\
\hline 2013 & 13.552 & 9.823 \\
2014 & 13.480 & 10.669 \\
2015 & 13.340 & 9.884 \\
2016 & 13.110 & 9.620 \\
2017 & 19.096 & 12.194 \\
\hline
\end{tabular}

Sumber: Direktorat Jenderal perkebunan (2017)

Berdasarkan Tabel 2, dapat dilihat bahwa luas lahan dan total produksi karet di Aceh Tamiang pada tahun 2013 sampai 2017 selalu berfluktuasi. Oleh karena itu peneliti tertarik untuk meneliti dan menganalisis risiko produksi karet alam petani di Kabupaten Aceh Tamiang tepatnya di Kecamatan Kejuruan Muda. Dari penjelasan tersebut dapat disimpulkan permasalahan dari penelitian ini adalah : (a) apa yang menjadi sumber risiko produksi karet, (b) bagaimana pengaruh dari faktor-faktor sumber risiko produksi terhadap produksi karet alam petani di Kecamatan Kejuruan Muda Kabupaten Aceh Tamiang, (c) bagaimana fluktualitas harga dalam mempengaruhi produksi karet di Kecamatan Kejuruan Muda Kabupaten Aceh Tamiang.

\section{Metode Penelitian}

Jenis penelitian ini adalah penelitian kuantitatif dan kualitatif. Metode penelitian yang digunakan adalah survei yang dilakukan dengan cara menyebar kuesioner dan 
melakukan wawancara. Lokasi penelitian dilakukan di Kecamatan Kejuruan Muda Kabupaten Aceh Tamiang. Sumber data penelitian ini adalah masyarakat yang tinggal di Kecamatan Kejuruan Muda Kabupaten Aceh Tamiang. Penelitian ini merupakan sebuah penelitian tentang Analisis Risiko Produksi Karet Alam Petani di Kecamatan Kejuruan Muda Kabupaten Aceh Tamiang. Penelitian ini dilakukan dari mulai pengambilan data awal pada bulan November 2018-Maret 2019.

Untuk tujuan pertama yaitu mengetahui sumber risiko produksi karet di Kecamatan Kejuruan Muda Kabupaten Aceh Tamiang, dan untuk tujuan ketiga menganalisis fluktualitas harga dalam mempengaruhi produksi karet di Kecamatan Kejuruan Muda Kabupaten Aceh Tamiang. Penulis menggunakan alat analisis deskriptif kualitatif. Deskriptif kualitatif merupakan alat analisis dalam meneliti status kelompok manusia, suatu objek, suatu set kondisi, suatu sistem pemikiran, ataupun suatu kelas peristiwa pada masa sekarang dengan tujuan membuat deskripsi, gambaran atau lukisan secara sistematis, fluktual dan akurat mengenai fakta-fakta, sifat-sifat serta hubungan antarfenomena yang diselidiki (Nazir, 2005).

Sedangkan untuk tujuan kedua menganalisis pengaruh dari faktor-faktor sumber risiko produksi terhadap produksi karet alam petani di Kecamatan Kejuruan Muda Kabupaten Aceh Tamiang. Penulis menggunakan alat analisis regresi linier berganda. Sedangkan uji hipotesis menggunakan uji F, uji t, dan $\mathrm{R}^{2}$ (koefesien determinasi)

Bentuk model dari regresi linear dari penelitian ini adalah :

$\left.Y=c+b_{1} X_{1}+b_{2} X_{2}+e \ldots \ldots . .1\right)$

Nilai dugaan parameter dari model ini adalah b1, b2, b4 $<0$; b7Y $(\mathrm{t}-1)>0$

Keterangan :

$\mathrm{Y}=$ Produksi $(\mathrm{Kk} \mathrm{Kg})$

$\mathrm{X}_{1}=$ Jumlah Pohon Yang Mati

$\mathrm{C}=$ Konstanta

$\mathrm{B}=$ Koefisien Regresi

$\mathrm{X}_{2}=$ Jumlah Pohon Yang Terkena Penyakit

\section{Hasil dan Pembahasan}

\subsection{Karakteristik Pedagang Karet}

Karakteristik petani dalam penelitian ini yaitu meliputi umur, pendidikan, pengalaman dan jumlah tanggungan keluarga. Adapun rata-rata karakteristik petani karet yang menjadi sampel penelitian dapat dilihat pada Tabel 3.

Tabel 3. Rata-rata Karakteristik Petani Karet di Kecamatan Kejuruan Muda Kabupaten Aceh Tamiang Tahun 2019

\begin{tabular}{lrrrc}
\hline Desa Sampel & $\begin{array}{c}\text { Umur } \\
\text { (Tahun) }\end{array}$ & $\begin{array}{c}\text { Pendidikan } \\
\text { (Tahun) }\end{array}$ & $\begin{array}{c}\text { Pengalaman } \\
\text { (Tahun) }\end{array}$ & $\begin{array}{c}\text { Jumlah } \\
\text { Tanggungan } \\
\text { (Jiwa) }\end{array}$ \\
\hline Bukit Rata & 49,67 & 9,00 & 36,50 & 3 \\
Pangkalan & 54,17 & 10,00 & 29,17 & 3 \\
Sidodadi & 50,67 & 9,00 & 25,17 & 4 \\
Purwodadi & 50,00 & 11,33 & 23,33 & 5 \\
Suka Makmur & 41,29 & 10,71 & 11,86 & 3 \\
Seumadam & 40,00 & 10,20 & 14,20 & 4 \\
\hline Rata-rata & 47,63 & 10,04 & 23,37 & 3 \\
\hline
\end{tabular}


Berdasarkan tabel diatas dapat dilihat bahwa rata-rata umur petani karet di Kecamatan Kejuruan Muda adalah 47,63 tahun dengan tingkat pendidikan rata- rata SMP dan pengalaman berusahatani sekitar 23,37 tahun serta jumlah tanggungan keluarga ratarata 3 jiwa.

\subsection{Produksi Karet Alam di Kecamatan Kejuruan Muda}

Produksi karet alam di Kecamatan Kejuruan Muda setiap petani berbeda- beda tergantung luas lahan dan perawatan yang dilakukan petani. Produksi karet alam dalam penelitian ini merupakan hasil panen karet yang diperoleh petani dalam satu bulan yang dihitung dalam satuan kilogram per bulan. Total hasil produksi dan ratarata hasil produksi karet petani di Kecamatan Kejurunan Muda pada saat dilakukannya penelitian dapat dilihat pada Tabel 4.

Tabel 4. Total Hasil Produski dan Rata-rata Hasil Produksi Karet Petani di Kecamatan kejuruan Muda Kabupaten Aceh Tamiang Tahun 2019.

\begin{tabular}{ccc}
\hline Desa Sampel & $\begin{array}{c}\text { Total Hasil Produksi } \\
(\mathrm{Kg} / \text { Bulan })\end{array}$ & $\begin{array}{c}\text { Rata-Rata Hasil Produksi } \\
(\mathrm{Kg} / \text { Bulan })\end{array}$ \\
\hline Bukit Rata & 900 & 300 \\
Pangkalan & 686 & 114,33 \\
Sidodadi & 1.075 & 179,17 \\
Purwodadi & 380 & 126,67 \\
Suka Makmur & 1.525 & 217,86 \\
Seumadam & 848 & 169,60 \\
\hline Jumlah & 5.414 & 158,23 \\
\hline
\end{tabular}

Berdasarkan tabel diatas terlihat bahwa total hasil produksi karet petani per bulan di desa sampel Kecamatan Kejuruan Muda sebesar $5.414 \mathrm{Kg} /$ Bulan dengan rata-rata hasil produksi per bulan 158,23 Kg/Bulan per luas lahan yang dimiliki petani. Desa sampel dengan tingkat hasil produksi yang tinggi terdapat di Desa. Suka Makmur yaitu sebesar $1.525 \mathrm{Kg} /$ Bulan. Hal ini dikarenakan masyarakat di Desa Suka Makmur sebagian besar berprofesi sebagai petani karet.

\subsection{Risiko Produksi Karet Alam di kecamatan Kejuruan Muda}

Risiko pada komoditi pertanian khususnya komoditi karet sangat rentan dalam mempengaruhi produksi yang dihasilkan. Risiko produksi karet di Kecamatan Kejuruan Muda dipengaruhi oleh beberapa faktor yang mengakibatkan hasil tidak optimum dan merata di setiap desanya. Adapun sumber-sumber risiko produksi karet alam di Kecamatan Kejuruan Muda yaitu sebagai berikut :

1. Cuaca/Iklim

Kondisi alam seperti cuaca dan iklim menjadi suatu ketidakpastian (uncertainty), karena merupakan bagian risiko yang harus dihadapi oleh petani yang tidak dapat diukur, salah satunya petani karet. Iklim di Kecamatan Kejuruan Muda yang termasuk dalam iklim tropis dan cocok ditanami tanaman karet memiliki pengaruh terhadap hasil produksi karet alam petani. Unsur cuaca/iklim yang sangat berpengaruh terhadap hasil produksi karet di Kecamatan Kejuruan Muda yaitu curah hujan dan angin. Kecamatan Kejuruan Muda memiliki dua musim yaitu musim penghujan dan musim kemarau. Saat memasuki bulan penghujan sebagian besar petani di desa sampel di Kecamatan Kejuruan Muda mengalami penurunan hasil produksi karena hal ini dapat mengganggu penyadapan, akan tetapi untuk beberapa petani yang 
menggunakan jenis karet tertentu pada saat musim penghujan mengalami peningkatan produksi. Saat memasuki bulan kemarau ada juga beberapa petani yang mengeluh bahwa hasil produksi menurun dikarenakan musim trek. Musim trek merupakan salah satu musim ketika daun tanaman karet mulai berguguran dan kadar getah mulai menurun sehingga mempengaruhi hasil produksi karet. Sedangkan untuk unsur cuaca/iklim seperti angin juga memiliki pengaruh terhadap produksi karet yaitu angin yang kencang dapat mengakibatkan kerusakan pada tanaman karet seperti patah cabang maupun tumbang. Hal ini dapat mengakibatkan berkurangnya hasil produksi karet.

2. Hama dan Penyakit

Hama dan penyakit merupakan salah satu faktor yang mempengaruhi hasil produksi karet. Penyakit yang menyerang tanaman karet petani di Kecamatan Kejuruan Muda yaitu penyakit fomes (jamur akar putih) yang mengakibatkan beberapa pohon karet tidak dapat berproduksi lagi, Cara petani dalam mengatasi penyakit fomes adalah dengan cara menyemprotkan fungisida pada tanaman karet yang masih sedikit ditumbuhi jamur dan mencabut pohon karet hingga akar- akarnya, kemudian membersihkan lahan bekas fomes tersebut agar penyakit ini tidak dapat menular kepada pohon karet lainnya. Kebersihan lahan merupakan hal yang sangat penting untuk mengatasi penyakit ini, karena jamur ini sifatnya adalah menular atau parasit fakultatif. Selain itu, jamur ini juga tidak dapat bertahan lama tanpa adanya sumber makanan. Hal ini menunjukkan bahwa timbulnya fomes sangat ditentukan oleh adanya sisa-sisa tunggul dan akar tanaman di lahan areal perkebunan karet.

\subsection{Analisis Pengaruh Faktor-Faktor Sumber Risiko Terhadap Produksi di Kecamatan Kejuruan Muda}

Hasil dan variabel yang diteliti dalam analisis pengaruh faktor sumber risiko terhadap produksi yaitu jumlah pohon yang mati, jumlah pohon yang terkena penyakit, cuaca/curah hujan dan produksi karet bulan sebelumnya. Hasil pendugaan persamaan faktor-faktor sumber risiko produksi dapat dilihat pada Tabel 5.

Tabel 5. Hasil Pendugaan Persamaan Faktor-Faktor Sumber Risiko Produksi di Kecamatan Kejuruan Muda Kabupaten Aceh Tamiang 2019.

\begin{tabular}{lcr}
\hline Variabel & Koefisien & \multicolumn{2}{c}{ Std. Error } \\
\hline Konstanta & 97,479 & 16,545 \\
Jumlah Pohon Yang Mati & 7,425 & 1,482 \\
Jumlah Pohon Yang & 4,349 & 1,420 \\
Terkena Penyakit & & \\
\hline
\end{tabular}

Salah satu alat analisis yang digunakan untuk mengetahui faktor-faktor sumber risiko produksi yang dapat mempengaruhi produksi karet di Kecamatan Kejuruan Muda Kabupaten Aceh Tamiang dalam penelitian ini adalah dengan menggunakan metode regresi linier berganda. Persamaan hasil analisis regresi linier berganda yaitu sebagai berikut:

$Y=97,479+7,425 X_{1}+4,349 X_{2}$

Hasil persamaan dapat dijelaskan sebagai berikut : (a) jumlah pohon yang mati (X1), hasil pendugaan parameter pada persamaan faktor-faktor sumber risiko produksi menunjukkan untuk variabel jumlah pohon yang mati (X1) memiliki tanda positif yang berarti menunjukkan bahwa ada pengaruh positif terhadap produksi (Y). Hal ini 
menjelaskan bahwa apabila setiap jumlah pohon yang mati meningkat satu pohon, maka hasil produksi akan meningkat sebesar 7,425 kilogram karet kering (Kg KK) dengan asumsi variabel lainnya tetap. (b) Jumlah pohon yang terkena penyakit (X2), variabel kedua dalam penelitian ini adalah variabel jumlah pohon yang terkena penyakit (X2). Hasil analisis yang diperoleh pada variabel ini memiliki tanda positif yang berarti menunjukkan bahwa ada pengaruh positif terhadap produksi (Y). Hal ini menjelaskan bahwa apabila setiap jumlah pohon yang terkena penyakit meningkat satu pohon, maka hasil produksi akan meningkat sebesar 4,349 kilogram karet kering (Kg KK) dengan asumsi variabel lainnya tetap.

\subsection{Analisis Fluktualitas Harga Dalam Mempengaruhi Produksi Karet}

Fluktuasi harga merupakan perubahan naik atau turunnya harga suatu barang sebagai akibat dari mekanisme pasar. Fluktuasi harga pada komoditi pertanian dilihat dari kenyataan-kenyataan yang berlangsung di masyarakat, dengan adanya patokan harga dari pemerintah yang telah ditetapkan dan dikendalikan dengan baik. Komoditi karet merupakan salah satu komoditi pertanian yang mengalami ketidaktetapan harga (fluktuasi harga). Hal ini yang dialami petani karet di Kecamatan Kejuruan Muda. Rata-rata harga jual karet di Kecamatan Kejuruan Muda Kabupaten Aceh Tamiang dapat dilihat pada Tabel 6.

Tabel 6. Rata-Rata Harga Jual Karet di Kecamatan Kejuruan Muda Kabupaten Aceh Tamiang 2019.

\begin{tabular}{cc}
\hline Desa Sampel & Rata-Rata Harga Jual Karet $(\mathrm{Rp} / \mathrm{Kg})$ \\
\hline Bukit Rata & 8.067 \\
Pangkalan & 7.000 \\
Sidodadi & 8.167 \\
Purwodadi & 8.500 \\
Suka Makmur & 6.857 \\
Seumadam & 8.500 \\
\hline Rata-rata & 6.727 \\
\hline
\end{tabular}

Fluktuasi harga berpengaruh pada peningkatan jumlah produksi karet di Kecamatan Kejuruan Muda. Setelah dilakukannya penelitian dapat diketahui bahwasanya petani apabila harga naik maka mereka akan meningkatkan penyadapan sehingga berpengaruh terhadap peningkatan jumlah produksi dan apabila harga turun maka penyadapan tetap dilakukan seperti biasa. Tetapi untuk beberapa petani lainnya harga yang naik ataupun turun tidak mempengaruhi dalam peningkatan jumlah produksi karet.

\subsection{Uji Koefesien Determinasi, Uji F, Uji t}

Berdasarkan hasil uji koefisien determinasi diatas dapat disimpulkan sebagai berikut : $\mathrm{R}=0,504$ yang berarti hubungan antara variabel bebas (jumlah pohon yang mati dan jumlah pohon yang terkena penyakit) terhadap variabel terikat (produksi) adalah kuat. $\mathrm{R}^{2}$ sebesar 0,710 menyatakan jumlah pohon yang mati dan jumlah pohon yang terkena penyakit berpengaruh terhadap produksi karet alam di Kecamatan Kejuruan Muda sebesar $71 \%$ dan sisanya sebesar $29 \%$ dapat dijelaskan oleh faktor-faktor lain yang tidak diteliti dalam penelitian ini.

Uji F dilakukan untuk mengetahui apakah variabel bebas (jumlah pohon yang mati, jumlah pohon yang terkena penyakit) mampu secara bersama-sama mempengaruhi 
variabel terikat (produksi). Dari hasil pengujian SPSS diperoleh nilai $F=18,864$ dengan tingkat signifikan 0,001. Adapun hasilnya dapat dilihat pada Tabel berikut ini :

Tabel 7. Hasil Uji Simultan/Serempak Uji F terhadap Variabel

\begin{tabular}{lcrcc}
\hline \multicolumn{1}{c}{$a$} & F & \multicolumn{2}{c}{ Sig } & \multicolumn{2}{c}{ Kesimpulan } \\
\hline $\begin{array}{l}a=0,05 \\
(95 \%)\end{array}$ & 13,736 & 0,000 & $0,000<0,05$ & $\begin{array}{l}\text { Variabel bebas } \\
\text { berpengaruh } \\
\text { terhadap } \\
(99 \%)\end{array}$ \\
\hline
\end{tabular}

Untuk melihat pengaruh secara parsial variabel-variabel bebas terhadap variabel terikat digunakan uji t. Hasil analisis uji t dapat dilihat pada Tabel 8.

Tabel 8. Hasil Uji t Terhadap Masing-Masing Variabel

\begin{tabular}{lccccl}
\hline \multicolumn{1}{c}{ Variabel } & $\mathrm{a}$ & $\mathrm{t}$ & Sig. & Kesimpulan & \\
\hline Jumlah & $\mathrm{a}=0,05$ & 5,009 & 0,000 & $0,000<0,05$ & $\begin{array}{l}\text { Berpengaruh } \\
\text { (Signifikan) }\end{array}$ \\
$\begin{array}{l}\text { Pohon Yang } \\
\text { Mati (X1) }\end{array}$ & $\begin{array}{c}95 \%) \\
\mathrm{a}=0,01\end{array}$ & & & & \\
& $(99 \%)$ & & 0,000 & & \\
\hline Jumlah & $\mathrm{a}=0,05$ & 3,064 & 0,005 & $0,005<0,01$ & Berpengaruh \\
Pohon Yang & $(95 \%)$ & & & & (Signifikan) \\
Terkena & $\mathrm{a}=0,01$ & & 0,005 & & \\
Penyakit (X2) & $(99 \%)$ & & & & \\
\hline
\end{tabular}

\section{Simpulan}

Risiko produksi karet di Kecamatan Kejuruan Muda dipengaruhi oleh beberapa faktor yang mengakibatkan hasil tidak optimum dan merata di setiap desanya. Adapun sumber-sumber risiko produksi karet alam di Kecamatan Kejuruan Muda yaitu cuaca/iklim serta hama dan penyakit. Fluktuasi harga berpengaruh pada peningkatan jumlah produksi karet di Kecamatan Kejuruan Muda. Setelah dilakukannya penelitian dapat diketahui bahwasanya bagi beberapa petani apabila harga naik maka mereka akan meningkatkan penyadapan sehingga berpengaruh terhadap peningkatan jumlah produksi dan apabila harga turun maka penyadapan tetap dilakukan seperti biasa. Tetapi untuk beberapa petani lainnya harga yang naik ataupun turun tidak mempengaruhi dalam peningkatan jumlah produksi karet.

\section{Daftar Pustaka}

Direktorat Jenderal perkebunan. 2017. Statistik Perkebunan Indonesia. Jakarta (ID) : Sekretariat Direktorat Jenderal perkebunan.

Nazir, M. 2005. Metode Penelitian. Edisi keenam. Ghalia Indonesia: Bogor. 